\title{
THE ESTABLISHMENT OF CHARACTER FOR THE MILLENNIAL GENERATION THROUGH MORAL THERAPY: A STUDY OF THE NAZAM AZKIYA' MANUSCRIPT
}

Eka Kurnia Firmansyah ${ }^{1 *}$, Titin Nurhayati Mamun ${ }^{2}$, Ade Kosasih ${ }^{3}$

${ }^{1 *, 2,3}$ Universitas Padjadjaran, Bandung, West Java, Indonesia.

Email: ${ }^{1 *}$ eka.kurnia@unpad.ac.id, ${ }^{2}$ titin.mamun@unpad.ac.id, ${ }^{3}$ a.kosasih@unpad.ac.id

Article History: Received on $28^{\text {th }}$ March 2020, Revised on $21^{\text {st }}$ May 2020, Published on $19^{\text {th }}$ June 2020

\begin{abstract}
Purpose of the study: This research focused on the development of character for the millennial generation through moral therapy as can be found in the manuscript Nazam Azkiya'. Additionally, various teachings and guidance of the Wali were discussed in fostering the morals contained in the manuscript. This article also described the moral therapy and the form of teachings and guidance for peace seekers by exploring the values contained in these teachings and guidance.
\end{abstract}

Methodology: The method used in this research is detailed verification, using ex post facto and survey approaches employed to investigate the phenomena such that values can be analyzed extensively.

Main Findings: The results of the data analysis show that the condition of moral values and character of the millennial generation are in the high category, so are the social, environmental, and religious conditions. Therefore, the character building of the Millennial generation by employing a system of moral therapy based on the teachings of the Wali in the Nazam Azkiya manuscript is by first, instilling religious norms from an early age. Second, teaching the importance of courtesy. Third, instilling family values since childhood. Fourth, sharpening their will and drive. Fifth, familiarising them in socializing.

Applications of the study: The findings of this research could be used as a form of study and particularly towards the development of knowledge on tasawuf manuscripts and moral education. Furthermore, this article is expected to be used as a reference for scholars in applying knowledge in social life and enrich insights that are useful for the development of science. The expected outcome of this moral therapy is a change in the millennial's attitude and character towards a better and more responsible individual.

Novelty/Originality of the current study: This therapeutic system is the development of character for the Millennial generation, mainly in instilling intelligence, virtue and moral character, beneficial to others, can use gadgets and technology appropriately and according to their functions. Additionally, the Millennial generation should always be accompanied by religious teachings that can shape them into individuals with good disposition and morality.

Keywords: Character Building, Millennial Generation, Morals, Nazham Azkiya Manuscripts.

\section{INTRODUCTION}

The development and advancement of technology have now brought humans to the modern era or the digital era. This can be seen from the vast array of available gadgets and information that can be accessed easily by everyone. In this modern era, all people ranging from children, adolescents, and parents have been expected to follow the flow of existing technological developments, otherwise, they will be considered as outdated people.

Since the emergence of the generation theory, we have been introduced to the term baby boomers or the generation born in 1946 - 1964 or after World War II. They were named as such due to the increased number of offspring found in this generation. After the baby boomers are generation X, born in 1965 - 1980. This generation lived in the emergence of PCs, video games, cable TV, and the internet. After generation X, generation Y was born in $1981-1994$. This generation is also called millennials. This generation has started to use instant communication technologies such as emails, SMS, Facebook, and so forth. Following the millennials is generation Z, born in $1995-2010$. This generation is also called i-Generation, net generation, or internet generation. They have something in common with Generation Y, which is the ability to multitask (Ali \& Purwandi, 2017; Burstein, 2013).

Millennial is a term in demographics, a noun means followers or groups. Currently, there are four major demographics, namely Baby Boomers (born 1946-1964), Gen-X (born 1965-1980), Millennials (born 1981-2000), and Gen-Z (born 2001-present). In another literature the millennial generation is the generation born between 1982 and 2002, however, this difference is not too significant (Ali \&Purwandi, 2017; Rebollo, 2018; Alam, Marijan, Aminah, \& Putranto, 2020; Balda \& Mora, 2011; Burstein, 2013).

Thanks to the changes brought by previous generations, Millennials are now known as the most influential generation in human life. They are supported by technology and can even affect the world economic cycle. The characteristics of the Millennial generation include high learning, dehumanization, life assisted by high-tech gadgets, obsession with new objects/tools/products and they will exchange them with new ones once they feel bored. No surprise that it is predicted 
that most of them are obese or have excessive body weight due to lack of movement, caused by living in a world of technology, all are at the tip of a finger without leaving the house (Chaudhuri, 2020; Cody, 2020).

Currently, we are entering an era of the Millennials, the generation born in 1982 - 2002. The millennial generation is considered a smarter generation because technology is increasingly advanced followed by the changing ways of communicating and socializing. They are more expressive and high-tech because they live in the information age. However, the millennial generation is also predicted to be lonely than other generations because of the lesser number of siblings. Since they interact more with technology, they tend to be ignorant even antisocial (Alam, Marijan, Aminah, \& Putranto, 2020).

Being the parents of the smartest generation is not simple. It is undeniable that all the technology the millennials can access also has bad impacts. Easy access to a wide range of information also opens up opportunities for bad occurrences. There are several negative impacts of technological advances that can affect the Millennials, including selfishness and lack of attention to values. Since they were born, they have lived in a world with rapid technological developments. Gadgets have become a part of their lives to the fullest. They grew up with iPad in hand, cannot live without smartphones, and can operate gadgets only by recognizing the buttons. Hence, they are considered as the most transformative generation.

Millennials are the most influential generation in human life. They affect the world economic cycle, as they consume toys, food, clothing, and new technological devices that exist today. The rapid progress of this technology in the future will affect them, ranging from lifestyles, ways of learning, materials learned at school, up to their daily relationships. Space and time are no longer a limit, distance is increasingly meaningless, the association is no longer determined by location factors. Not surprisingly, from everything that could be obtained, the Millennial generation becomes smarter than previous generations.

Every generation has both positive and negative impacts, and to educate the Millennial generation requires religious education and character and manner building as well as instilling ukhuwah values or socializing. Among the therapeutic systems for the Millennials is to understand and teach them the teachings and tariqat guidance of the Wali as stated in the Nazam Azkiya manuscript to avoid being immersed in the delusion of worldly pleasures and dehumanization.

The victims of dehumanization lose their sensitivity to noble values, such as truth, goodness, beauty (aesthetic), and purity. They only respect basic values, such as material (wealth), hedonism (physical pleasure) and prestige. These three values form a large part of the value basis in our society today. Since they are not supported by higher values, especially the values of goodness (ethics, morals) and purity (religion), they justify all means, such as corruption, collusion and nepotism and (even) violence is a legal way to obtain these basic values. Immorality, obscenity and compaction are reasonable behaviours; prestige, as opposed to self-esteem (sense of honour), manifests itself in a shameless nature and even tends to boast of the result of the crime. Those are the lifestyle suitable for people with low values as a result of the dehumanization (Wibowo, Nurhaji, Setiawan, Sugiyarto, Noor, Faizin,... \& Coștu, 2018).

Semantically, dehumanization occurs when the noble values that exist in the ideological, cultural, and religious texts no longer function effectively as a guide to everyday human life, causing the culture loses collective support and humans tend to live without cultural nobility.

The process of globalization, with all the advances in information and communication technology, also leads to a process of dehumanization, in which humans assume they are not equal. When one considers others to be in a lower position, empathy does not arise when he experiences distress, sadness or pain.

The Nazam Azkiya manuscript is Sufism poems in Arabic and Sundanese in the form of teachings, messages, and guidance for Muslim scholars to guide the millennial generation towards a better direction. Because happiness is not measured by the amount of material but rather obtained based on a qana'ah lifestyle. It also contains the teaching about self-purification, elaborating the guidance to achieve happiness and moral therapy for the Millennial generation from all qualities that can damage the soul.

This manuscript is interesting to study because it contains the main points of religious teachings useful for humanity. It was written using the Pegon script, where most people from the current generation can no longer read it. Therefore, the following text edits and translations become important. Therefore, based on the above discussion the objectives of the current study are:

1. To investigate and explain the importance of the Nazam Azkiya manuscript for society.

2. To examine the form and content of the manuscript.

3. To explain the ways through which the manuscript can be used as a moral therapy in shaping the character of the Millennial generation to avoid dehumanization. 


\section{LITERATURE / PREVIOUS RESEARCH}

The millennial generation is a title for individuals or groups who prefer being instant in everything, implying of unwanted to be burdened by time in achieving their desired goals. This has become an opportunity for business people, especially those who engage in online businesses. In the online system, everything has detailed information to ease customers in placing orders. With these conveniences, people will be persuaded by the technology offered. It influences individuals to be passive while trying to achieve results (Hidayatullah, Waris, \& Devianti, 2018; Al-khresheh, Khaerurrozikin, \& Zaid, 2020; Bell, 2005).

Online lifestyle has become part of the soul of a millennial. No wonder that diverse advertisements for goods and services are channelled to millennials through various media platforms. The invitation to shop echoes since people wake up do their errands, until returning home. Unsurprisingly, they have become consumptive and do not hesitate to spend money on products or services. Millennials are consumers who dominate the market today, creating business opportunities for business-minded people, especially online businesses (Hidayatullah et al., 2018; DiLullo, McGee, \& Kriebel, 2011; Dolby, 2014; Etgar \& Tamir, 2020; Gani, 2019; Gurman \& Fraenkel, 2002).

According to Sumartono (1998), the concept of consumptive behaviour varies greatly, but in this context, it refers to purchasing goods or services without rational consideration nor based on needs.

In this global era, a person needs solid control in choosing and sorting numerous values offered to him. Therefore, the best way for someone to be resilient is through education. It is also the best way to build communities, countries, and the world. In simple words, the focus of education is only three: building knowledge, skills, and character. Based on these three elements, the main core is the character (Teng, Quoquab, Hussin, \& Mohammad, 2016; Wahana, 2015; Hulukati, Hulukati, \& Rahim, 2019; Kundanis, 2003; Petersen, 2020; Pirie\& Worcester, 1998).

According to Daradjat (1982), the moral decline of students is one result of the rapid development of technology unadjusted by an increase in the quality of character, despite technological advancements are necessary for striving in the globalization era. The moral decline is largely influenced by socio-cultural conditions in the community. Additionally, the poor social environment is a form of lacking social norms to control negative changes (Shams, 2016; Wahana, 2015; Ronda, Valor, \& Abril, 2020; Sandfort \& Haworth, 2002; Wibowo et al., 2018).

\section{METHOD}

The method in this research is descriptive verification, using ex post facto and survey approaches. According to Sugiyono (2010) ex-post, facto is a study to examine events that have occurred and trace them back to find out the factors causing the incident. While the survey method is research conducted on large and small populations, but the data studied comes from samples taken from these populations to find relative events, distribution, and relationships between variables. According to Sugiyono (2010), based on the type of data analyzed, this research belongs to quantitative research, which is research with numerical data or enumerated qualitative data.

This article is descriptive, research that intends to describe a particular social phenomenon, where there is existing information on social phenomena corresponding to the research problem but deemed inadequate. This research is usually to provide deeper explanations of social phenomena as intended in the research problem (Malo, 1985).

\section{RESULTS}

\section{Description of Respondents}

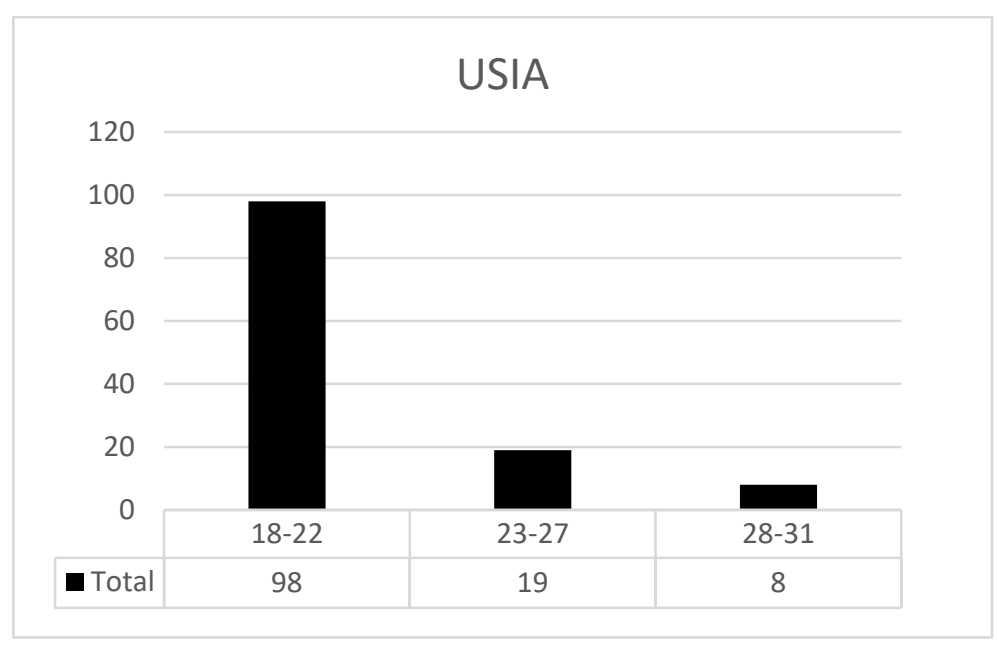

Figure 1: Age of respondents 
Based on the figure 1 above, it can be seen that the respondents in this study are millennials aged 18-22 years old (98 people, 78.4\%), 23-27 years old (19 people, 15.2\%), and 28-31 years old (8 people, $6.1 \%$ ).

Usia saya
125 responses

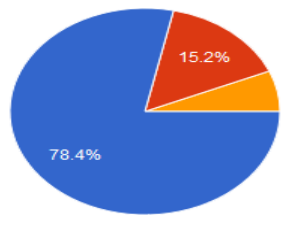

- $23-27$

28-31

Figure 2: Age group percentage

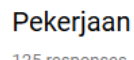

125 responses

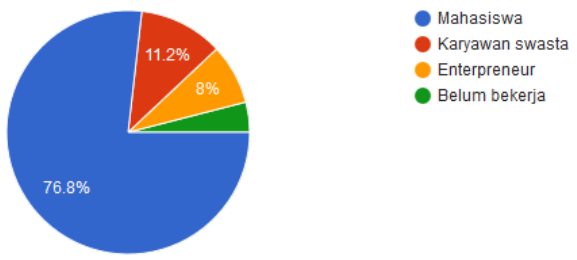

Figure 3: Occupation of respondents

Based on figure 3 above, the occupations of the Millennial respondents are $76.8 \%$ of students, private employees $11.2 \%$, entrepreneurs $8 \%$, and unemployed $4 \%$.

\section{Pendidikan}

125 responses

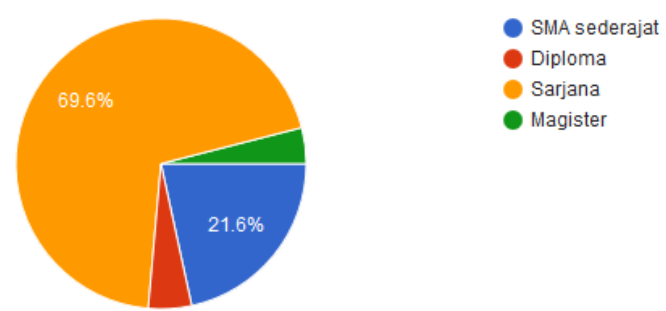

Figure 4: Education background

Based on figure 4 above, the educational background of the Millennial respondents is $21.6 \%$ high school, $69.9 \%$ bachelor degree.

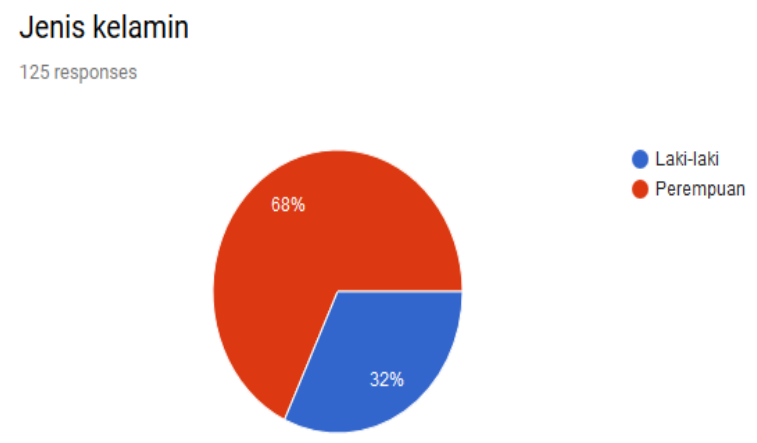

Figure 5: Gender of respondents

Based on figure 5 above, the gender of Millennial respondents is 32\% male and 68\% female. 


\section{Characteristics of the millennials}

- I like to read

\section{Saya senang membaca \\ 125 responses}

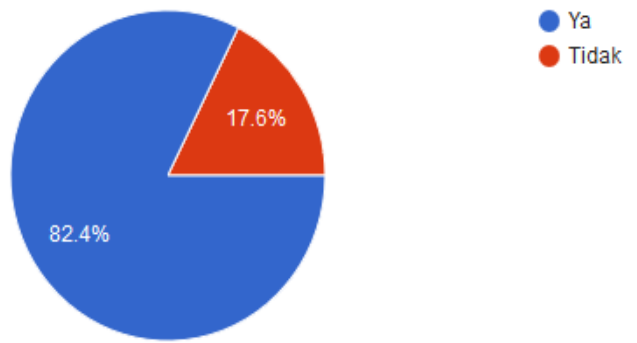

Figure 6: Reading as a hobby

Based on figure 6 above, the Millennial respondents who like to read are $82.4 \%$ while $17.6 \%$ do not.

- The types of books I like to read

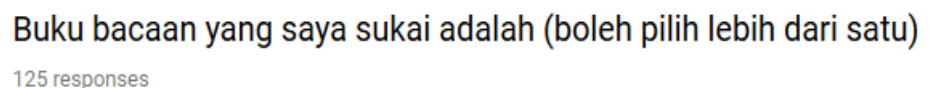

125 responses

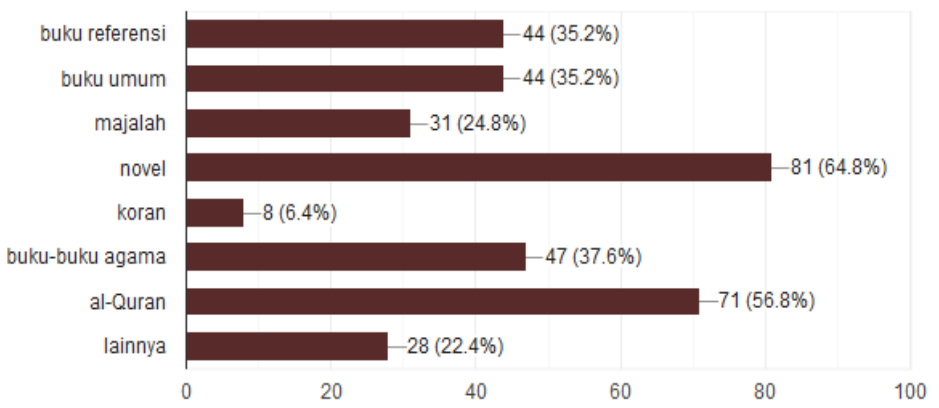

Figure 7: Types of books

Based on figure 7 above, the types of books the Millennial respondents like to read are reference books (35.2\%), general books $(35.2 \%)$, magazines $(24.8 \%)$, novels $(64.8 \%)$, newspapers $(6.4 \%)$, religious books (37.6\%), al-Quran (56.8\%), and others $(22.4 \%)$.

- I prefer using gadgets to reading books

\section{Saya lebih suka menggunakan Gadget daripada membaca buku}

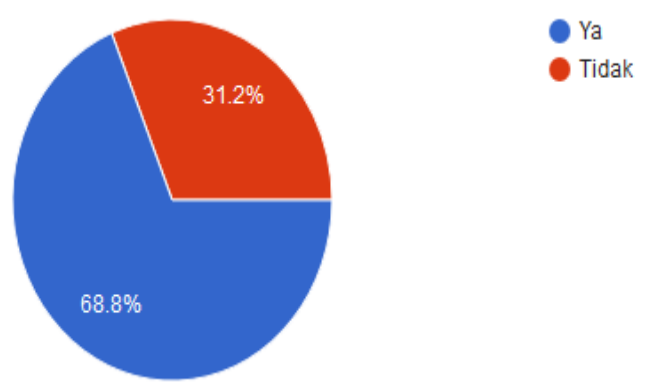

Figure 8: Preference for using gadgets than reading books 
Based on figure 8 above, the percentage of Millennial respondents who prefer using gadgets is $68.8 \%$, while $31.2 \%$ prefer reading books.

- I spend more time using gadgets than doing other works

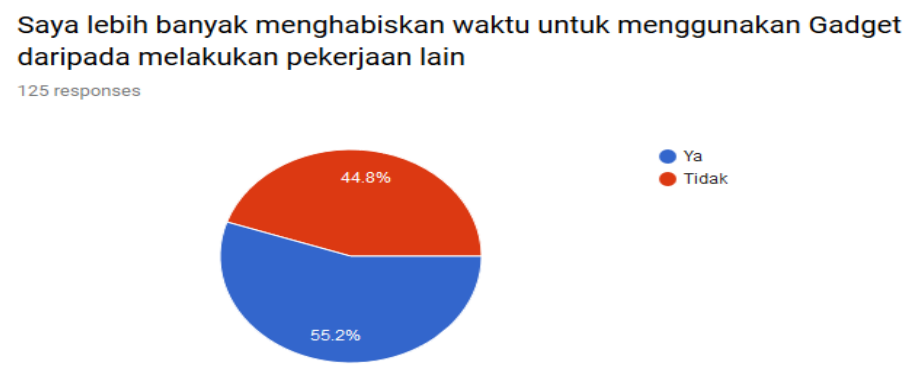

Figure 9: Time spent using gadgets

Based on figure 9 above, the percentage of Millennial respondents who agree that they spend more time using gadgets is $55.2 \%$ while $44.8 \%$ do not.

- I use gadgets for

Saya menggunakan Gadget untuk :

125 responses

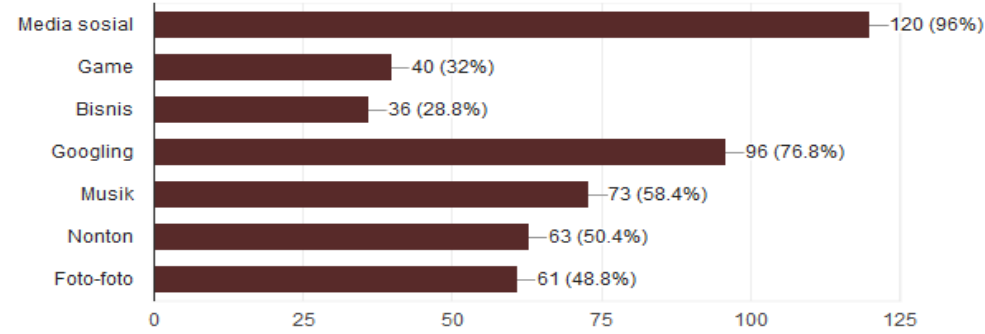

Figure 10: Gadget usage

Based on figure 10 above, the gadget usages by the Millennial respondents are for social media (96\%), playing games (32\%), business $(28.8 \%)$, googling $(76.8 \%)$, listening to music $(58.4 \%)$, watching videos $(50.4 \%)$, and taking photos $(48.8 \%)$.

\section{Skills and expertise}

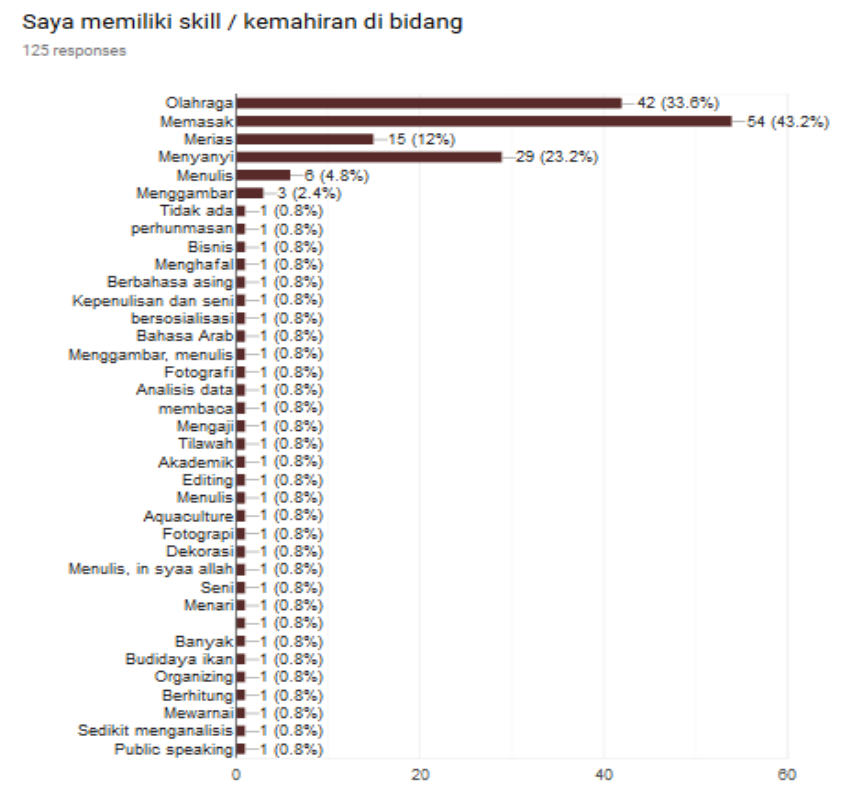

Figure 11: Skill/ Expertise 
Based on figure 11 above, the skills/expertise mastered by the Millennial respondents are sports (33.6\%), cooking (43.2\%), make up (12\%), singing (23.2\%), writing (4.6\%), and other skills (1\% each).

- I am very concerned about nutritious foods

\section{Saya sangat memperhatikan gizi untuk makanan saya}

125 responses

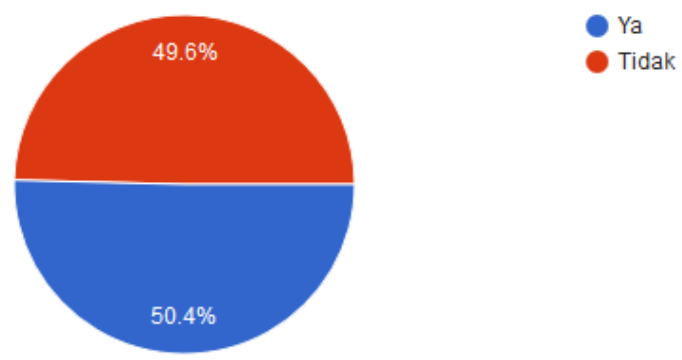

Figure 12: Concern about nutritious food

Based on figure 12 above, the percentage of Millennial respondents who concern about nutritious food is $50.4 \%$ while $49.6 \%$ do not.

- For me, eating vegetables is not important

\section{Bagi saya makan sayuran itu tidak penting

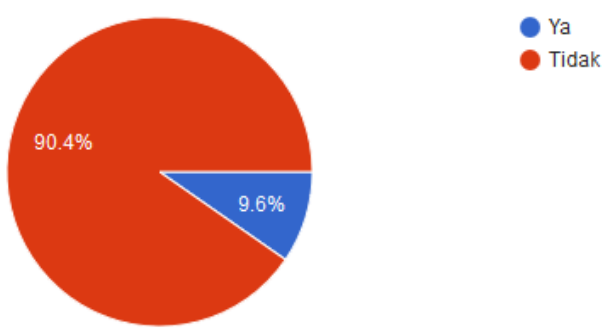

Figure 13: Eating vegetables is not important

Based on figure 13, the majority of the Millennial respondents (90.4\%) do not agree with the statement while $9.6 \%$ agree.

- After having a meal, I like to sleep

\section{Setelah makan saya suka tidur}

125 responses

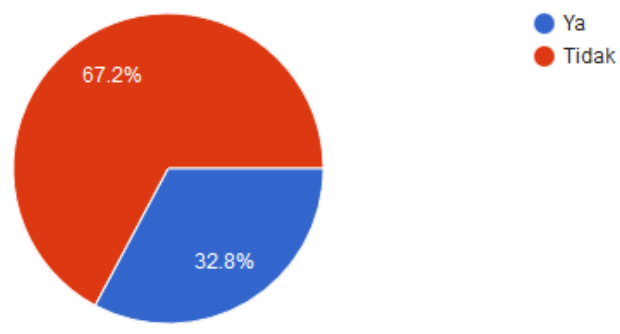

Figure 14: Habit after having a meal

Based on figure 14 above, $67.2 \%$ of Millennial respondents agree with the statement, while $32.8 \%$ do not.

- I like ordering food via online couriers 


\section{Saya senang memesan makanan via kurir online}

125 responses

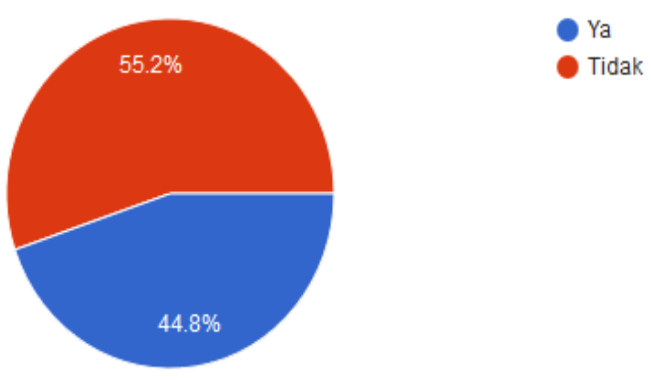

Figure 15: Food order via online couriers

Based on figure 15 above, $55.2 \%$ of the Millennial respondents like to order food via online couriers, while $44.8 \%$ do not.

- I often leave the prayers

\section{Saya suka meninggalkan solat}

125 responses
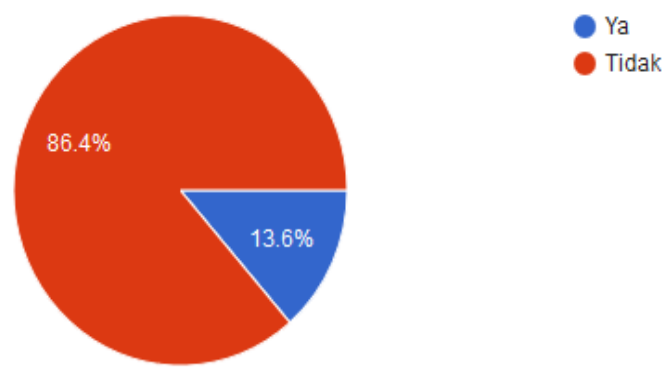

Figure 16: Leaving prayer

Based on figure 16 above, the majority of respondents (86.4\%) do not leave prayers, while $13.6 \%$ do.

- It is hard for me to pray on time

\section{Sukar sekali bagi saya untuk solat tepat waktu}

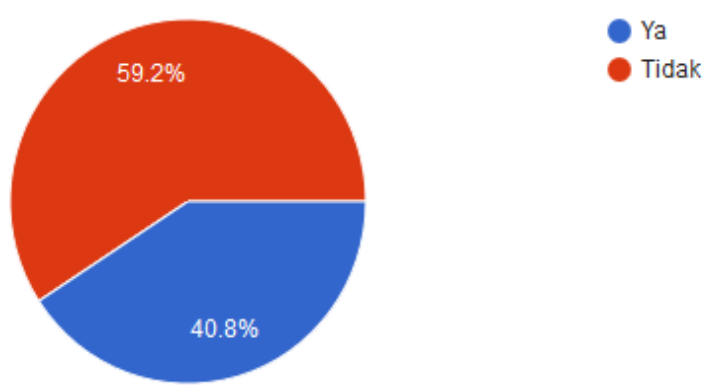

Figure 17: Difficulty praying on time

Based on figure 17 above, 59.2\% of the Millennial respondents do not find it hard to pray on time, while $40.8 \%$ do.

- I always take the time to read the Quran at least once a day 
Saya selalu menyempatkan diri membaca Quran minimal sekali dalam sehari

125 responses

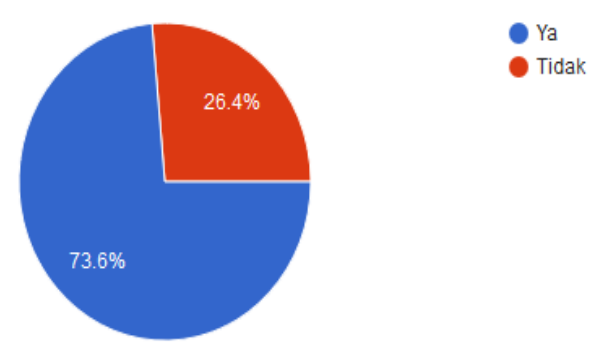

Figure 18: Reading the Quran

Based on figure 18 above, the majority of respondents (73.6\%) always take the time to read the Quran, while $26.4 \%$ do not.

- I always say thank you to anyone who helps me

\section{Saya selalu mengucapkan terima kasih kepada siapa saja yang membantu saya}

125 responses

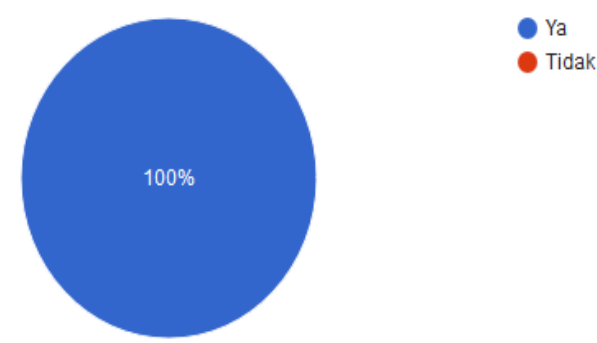

Figure 19: Saying thank you

Based on figure 19 above, all respondents (100\%) always say thank you to anyone who helps them.

- I will apologize to the person I hurt

\section{Saya akan meminta maaf kepada orang yang saya sakiti}

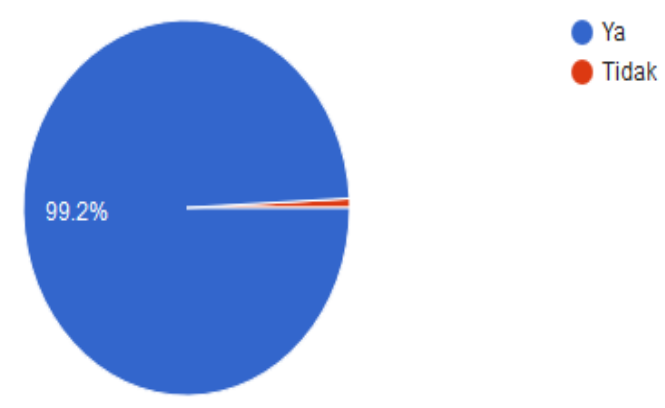

Figure 20: Apologising

Based on figure 20 above, $99.2 \%$ of respondents will apologize to the person they hurt, while $0.8 \%$ will not.

- I often argue with my father/mother at home 


\section{Di rumah, saya sering berdebat dengan ayah/ ibu saya}

\section{5 responses}

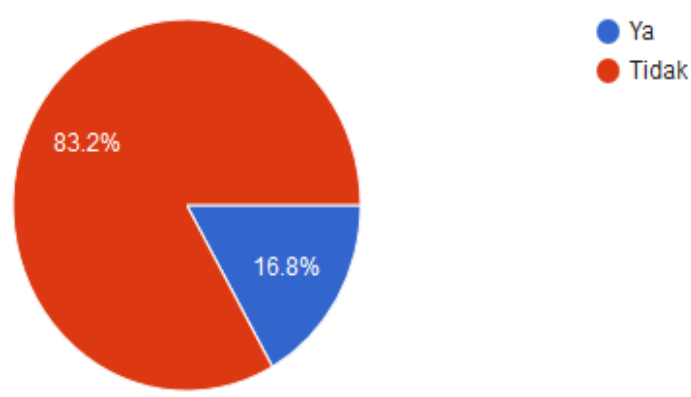

Figure 21: Arguing with parents

Based on figure 21 above, the majority of respondents (83.2\%) do not often argue with parents, while $16.8 \%$ do.

- I often challenge parental orders

\section{Saya sering membantah perintah orang tua}

125 responses

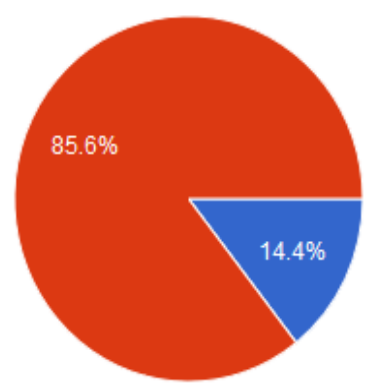

Figure 22: Challenging parental orders

Based on figure 22 above, the majority of respondents $(85.6 \%)$ do not often challenge parental orders, while $14.4 \%$ do.

- I will leave home to look for a job

\section{Saya akan merantau untuk mencari pekerjaan}

\section{5 responses}
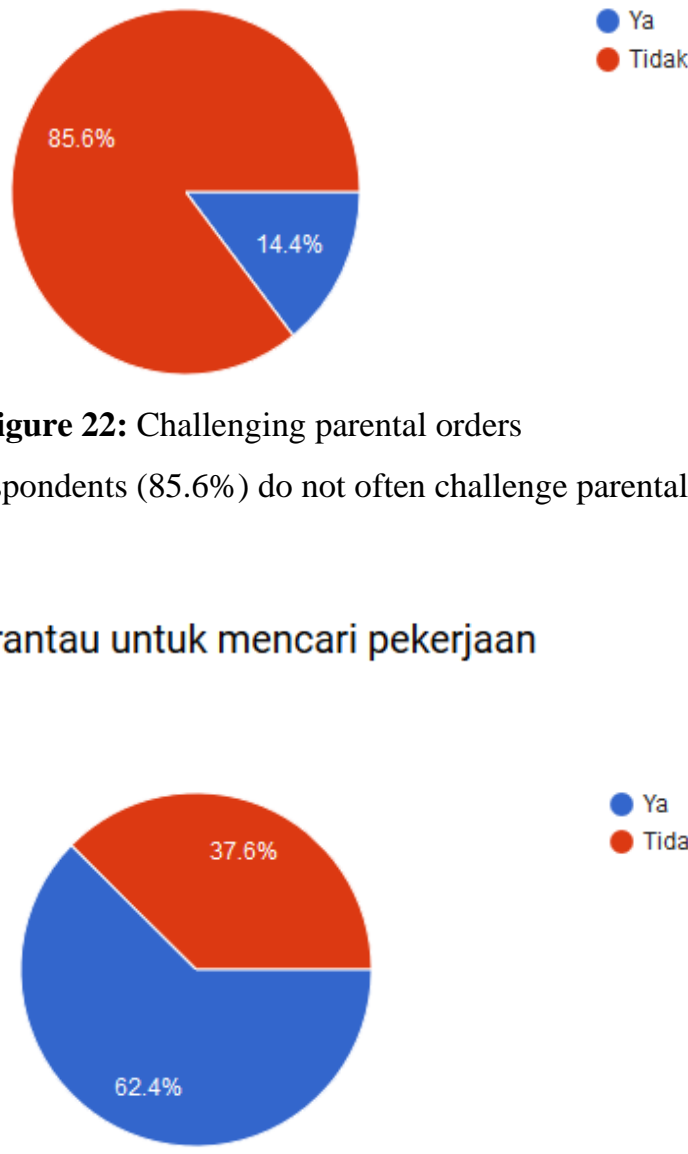

Tidak

Figure 23: Leaving Home to Look for a Job

Based on figure 23 above, $62.4 \%$ of the Millennial respondents will leave home to look for a job, while $37.6 \%$ will not.

- I will live independently 


\section{Saya akan mencoba hidup mandiri setelah menyelesaikan pendidikan}

125 responses

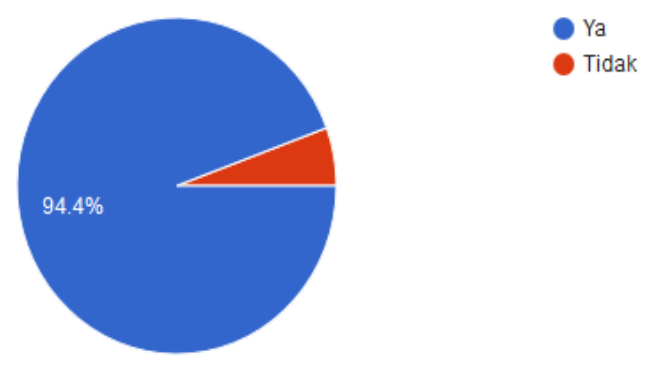

Figure 24: Independent life

Based on figure 24 above, the majority of respondents (94.4\%) will live independently, while $5.6 \%$ will not.

- I want to make my parents happy

\section{Saya ingin membahagiakan orang tua}

125 responses

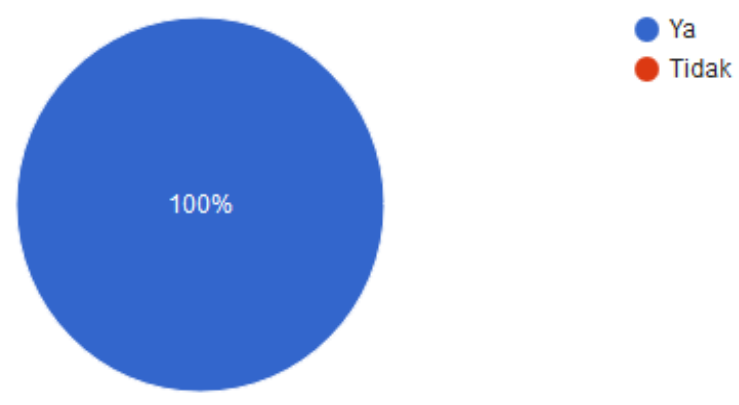

Figure 25: Makingparents happy

Based on figure 25 above, all respondents (100\%) want to make their parents happy.

- I greet the neighbours everyday

\section{Setiap hari saya selalu menyapa tetangga saya}

125 responses

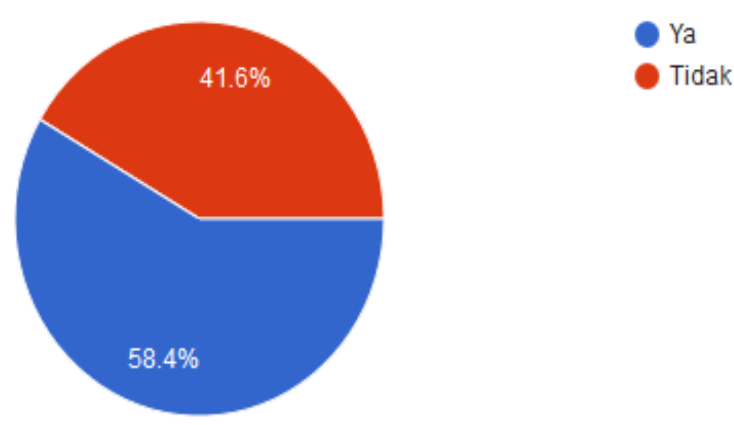

Figure 26: Greeting the neighbours

Based on figure 26 above, 58.4\% of the Millennial respondents always greet their neighbours, while $41.6 \%$ do not.

- I always use the words $P a k, B u, O m$, The, Kang to the elders 
Saya selalu menggunakan kata pak, bu, om, teh, kang kepada yang lebih tua saat berbicara dengan mereka

125 responses

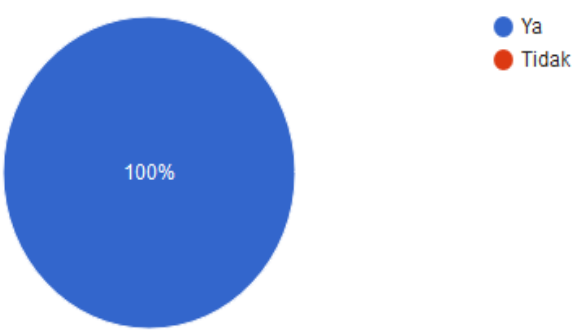

Figure 27: Nickname

Based on figure 27 above, all respondents (100\%) always use the words $P a k, B u, O m$, The, and Kang when talking to the elders.

- I always use nicknames to call my friends

\section{Saya selalu memanggil nama julukan kepada teman saya}

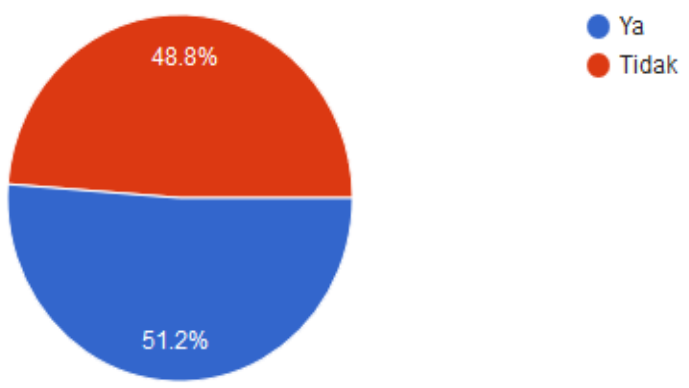

Figure 28: Nicknames

Based on figure 28 above, $51.2 \%$ of the Millennial respondents always use nicknames to call their friends, while $48.8 \%$ do not.

This Validity Test showed the extent of the instrument in measuring intended objects (Sugiyono 2010). The 23 indicators examined above-contained measurements for the moral and character of the Millennial respondents, particularly the students.

\section{DISCUSSION}

Characteristics of the Millennial generation are sheltered, placing technology as a lifestyle, born of educated parents, multi-talented, multi-language, expressive and explorative, confident, optimistic, preferring simplicity and instant options (Dolby, 2014). They also consider that achievement is something that must be accomplished. Teamworks are more effective and interactive for their works and studies through collaboration and group thinking. They are also independent and structured in using technology, communication gadgets, and the internet, thus encouraging the openness to various cross-border information. The Millennials tend to be more permissive to diversity but do not care about privacy and are willing to share intimate details about themselves with strangers. Through social media, it is a culture to write a status on their daily activities (cyberculture). This prompts all cultural activities are carried out in an unlimited virtual world. However, they still maintain the principle that family is an important pillar of their lives (Hulukati, Hulukati \& Rahim, 2019; Kundanis, 2003).

The Millennials need to learn self-control from the sophistication of technology and an instant lifestyle to prevent them end their lives due to depression, pressure, bullying, breakup, and so on.

Through the study of Nazam Ażkiya manuscript, it was found that by understanding the guidance and carrying out in daily lives are the beginning of happiness. Happiness is not necessarily from the material entity, but it can be experienced whenever and wherever people are close to God (Burstein, 2013; Gani, 2019). 
The guideline begins by mapping the core purpose of humans, which is devotion to Allah Almighty. It is followed by mapping the position of Shari'a, tariqat, and hakikat. After that, the sequence of the Wali's messages is described. It consists of repentance, qana'ah, zuhud, studying the science of shara', maintaining sunna and manners, tawakkal, ikhlas, uzlah, and managing time.

This Nazam Ażkiyā manuscript contains teachings, messages, and guidelines for the Millennials from the Wali. The contents of the Muqadimah (Introduction) include:

1. Taqwa to Allah is a way of salvation.

2. Indulge in unlawful lust is the beginning of damage.

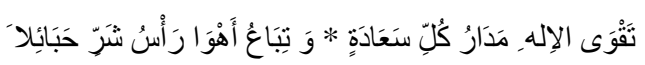

"Taqwa to Allah is the core of happiness \# While indulging in lust is the core of evil"

3. The afterlife-oriented way is by learning shari'a, tariqat, and hakikat.

4. Shari'a is like a boat, while tariqat is the sea and hakikat is the precious diamond

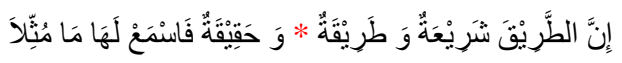

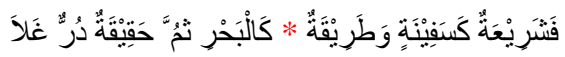

"Indeed, the road to the hereafter is Shari'a, tariqat \# And hakikat, so pay attention to what the Sufis demonstrate later"

"Shari'a is like a boat, tariqat is \# the ocean, while hakikat is the precious diamond on the bottom of the ocean"

5. Whoever wants to pursue the way of the Wali, he should follow, maintain, and carry out the following message:

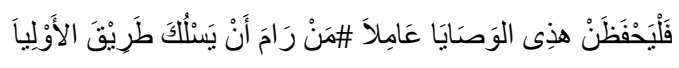

"Whoever wants to pursue the path of the Wali \# Then carry out their message/guidance tirelessly"

a) Repentance

- Protecting the eyes, tongue, and body limbs.

- Repentance is the key to worship.

- Whenever we are being tested, we should repent immediately.

b) Qona'ah/Feeling content

- It is advised to withdraw from any excessive desire from food, clothing, and home.

- Whoever seeks something useless, he will lose for abandoning something valuable.

c) Zuhud/Leaving love for worldly affairs

- Be zuhud and protect the heart from all desires for wealth that causes ignorance.

- Zuhud is best done after taqwa to achieve a high position.

- Be unmarried if the wife only interferes with worship; being single is a better option.

- There are four ways for salvation: 1. Forgive the fools, 2. Do not follow the path of fools, 3. Do not be happy if given something by someone else, 4 . Instead, donate/give others.

- Learning the science of Shari'a.

- Must learn sciences for assistance in worship and learn aqidah to cleanse the heart.

- Learning the three sciences is mandatory, then do carry out the message to gain dignity.

d) Maintain the sunnah of Rasulullah PBUH

- Maintain the sunnah, manners, and courtesy.

- Seek knowledge of tasawuf and al-'awarif.

- No worship but by following the teaching of the Prophet, from his manners to his sayings.

- Learn and analyze Riyạ̣̄̂ Al-Sālihin for achieving happiness.

- Emphasize the mandatory rites and do the sunnah as well. 
e) Tawakal/Surrender to God's plan

- Be tawakkal in seeking livelihood. Allah has promised to reward us with His prosperity.

- For married men, it is mandatory to seek livelihood while being tawakkal.

f) Ikhlas

- Ikhlas in every deed by wishing for His blessings.

- Do not pray merely for the praise nor by force.

- Do not be Riya in worship to be seen as better than others.

- Committing good deeds for praise is mushrik and Riya.

g) $A l^{\prime}-' U z l a h /$ Seclusion

- Do not mingle with fools who insult religions.

- Be parted with the flawed world.

- Avoid shubhat.

- According to some 'ulama mutaakhirin, uzlah should be done by now.

h) Hifžu Al-Auqāt/Managing Time

- Use time as well as possible only for worship, do not waste it.

- When fajr arrives, pray subuh and recite verses with khusyu'. Allah Almighty knows whether we are khusyu' in prayers.

- Do not leave congregational prayers that bear 27 times of rewards. After prayer, we should recite wirid and do not chat, face the qibla, do taqarrub, recite tahlil while sitting cross-legged.

- When the sun has risen to the height of a spear, do salahisyraq then recite the Quran?

i) Tażkiroh/Warning

- Whoever does not worship worldly affairs, he will be far from distress.

- Whenever feeling tired with Quran recitation, it can be replaced with zikr by heart and tongue.

- Whoever does not mujahadah, he will not benefit from the tariqat nor ma'rifat.

- Imam Suhro Wardi stated that mujahada is by reciting the Quran and zikr reciting kalimah tayibah.

- This the tariqat from the teachers, may we are eased in the undertaking.

Regarding time management, Millennials should be given guidance and training, as the scholars said: "time is like a sword, if we do not use it well, the sword will stab us ourselves". Starting from dawn by praying with khusyu', then do the congregational prayer in the mosque, and involve oneself in auraad (wirid) or zikr. When the sun has risen to the height of a spear, perform the Dluha prayer, remember death, then occupy oneself by seeking knowledge, worship, or working.

Millennials must be proficient in understanding the quantum of science; as explained in the contents of the manuscript that they must understand the virtues and importance of seeking knowledge, learning, and teaching. They should rectify the intention of learning to distinguish between the clerics of the world and the afterlife. The afterlife clerics are religious scholars while the world clerics are the ones with knowledge aiming for worldly pleasure, dignity, and position among people (Pirie \& Worcester, 1998).

Other teachings are about virtue for the reader of the Quran, the morals of a qari' and hafiz Quran who must always be zuhud, generous, well-mannered, welcoming, tolerant, patient, and virtuous. These are in line with the Millennial character building since they put priority in using gadgets wasting time and causing a moral decline. This is because no family nor the school environment to advise them. The parents are busy at work and school is only a part of a daily routine without positive impacts in their life.

To achieve positive impacts from the teaching and learning process at school, the students, especially the Millennials, should pay attention to the following learning manners: First, listen to the lecture attentively, do not criticize nor refute since it could corrupt the heart causing slow memory, or even worse by having life ends badly (su'u al-khatimah). Second, respect and honour the teachers (mu'allim), since respecting them means respecting knowledge. Knowledge can be obtained only by honouring the experts without criticizing them. Third, whenever encountering difficulties in learning, ask the teachers for the explanation. Fourth, before reading a book, compare it first with others that are true, straightforward, and trustworthy. Fifth, after rectifying the book, read the matan (main content) before the syarah 
(explanation). Do this repeatedly until it is preserved safely in the mind. Sixth, learn the tawhid first, followed by the science of the heart (ahwal al-qalb) and shari'a.

The important etiquette in the character building of the Millennials is dining manners (Kundanis, 2003; Petersen, 2020). It is known that they tend to have bad health due to obesity and junk/fast food. The treatment for this is explained in the Nazam Azkiya manuscript, it reads: Eat halal food; neither the doubtful nor the condemned ones. Nothing is more beneficial to the body and religion than eating less. The overfilled stomach has bad impacts, such as heavyweight, ruthless heart, loss of intelligence, sluggish body to worship God, and frequently sleeping. Thus, be careful of overeating!".

The therapy of eating halal food is prioritized in the character building of the Millennials. It is not advised to eat the food if its halal is doubted; even in consuming halal food, some rules must be observed. If it is done excessively, eating halal food becomes an act that Allah despises, as stated in Al'A'raf:31 that reads: “... and eat and drink, but be not excessive. Indeed, He likes not those who commit excess".

Rasulullah PBUH taught us to eat merely a few mouthfuls and a few gulps of water to straighten the backbone. If it has to be more than that, allocate the stomach one-third each for food, drink, and air. This way is better for the liver and heart. Overfilling stomach with food followed by drink will be too cramped for breathing. If done so, one will be confused and tired carrying it (the stomach) as if carrying a heavy load (Al-Malibary, 2004).

The followings are the impacts of the overfilled stomach and empty stomach according to the tariqat of the Wali:

Table 1: Impacts of the Overfilled Stomach and Empty Stomach

\begin{tabular}{clll}
\hline The Impacts of the Overfilled Stomach & \multicolumn{3}{c}{ The Benefits of an Empty Stomach } \\
\hline 1. Heavyweight & 1. & Purifying the heart, supporting talents, and permeating \\
2. Ruthless heart & the eyes of the heart \\
3. Loss of intelligence & 2. & Softening and purifying the heart \\
4. Too sluggish to pray & 3. & Eliminating lust and fostering humility \\
5. Frequent sleep & 4. & Reminding one of Allah's pleasure and punishment \\
& 5. & Eliminating the lust for immoral actions \\
& 6. & Preventing the urge to sleep and be awake at night \\
& 7. & Easing one to pray \\
& 8. & Resisting various diseases
\end{tabular}

Another therapy in establishing the character of the Millennials is by way of remembrance, as stated in the contents of the Nazam Azkiya manuscript: "the majority of ma'rifat scholars agrees that the most important obedience is to keep breathing in and out the word 'Allah', which can be done both in a crowd and solitude". This means that the most important form of worship is zikr, by guarding every breath that comes out of our mouth to include the words of Allah. Because, by remembering Allah, the heart will be peaceful.

The teachings of the Wali in the Nazam Azkiya manuscript explains that there are several procedures in zikr. First: to do it with perfect force in such that one will not feel a single space of air between the body cavities. Second: to do it by stretching the zikr from the navel to the brain. Third: when doing zikr, it is advisable to gather Allah's Great Characters and Names one by one. Fourth: in perfecting all the procedures of zikr, one should be in a state of holiness from large and small hadats, to face the Qibla, to clean the heart of worldly impressions, to remember Allah and to close one's eyes.

The preceding text has described the types of therapy for character building according to the teachings of the Wali as have been inscribed in the Nazam Azkiya manuscript. The following is a summary of those therapies:

1. Instilling religious norms from an early age;

The easiness of accessing technology requires parents to cultivate religious norms for their children since early childhood. Religious norms will fortify them as they grow up to explore the world. It will also make the children good at sorting out between good and bad.

This corresponds to the statement in the Nazam Azkiya manuscript that begins by mapping the core purpose of humans, namely fearing Allah and followed by mapping the position of Shari'a, tariqat, and hakikat. Subsequently, it mentions the steps that must be taken by a person who desires goodwills in the Afterlife. These include the message of the Wali, such as repentance, qana'ah, zuhud, studying the science of syara', maintaining the sunnah and manners, tawakal, to be sincere (ikhlas), uzlah and managing time.

\section{Teaching the importance of courtesy;}

Parents should befriend their children. However, this does not mean the child should treat their parents similar to a friend that they will lower their manners towards them. Children must remain to call their parents as "father" and "mother" and 
to not call them by their names because it is not polite. Parents must also be good at putting themselves in control of the relationship with their child.

Do not let the child dictate the parents to all decisions made. Therefore, teaching the importance of manners is very influential in children's personalities.

The manuscript of Nazam Azkiya explains that manners and noble character are the main characteristics of a knowledge seeker. It is useless for someone to be knowledgeable if he is immoral because morality is the initial foundation of the formation of human character.

3. Instilling family values since childhood;

Every family has different values from one another. However, each family must attempt at setting good examples for their children, so that the child can appreciate the positive values that exist in the family and applies it. Good values in the family should be applied in everyday life and are expected to be firmly rooted in the child's personality. The habit of loving, respecting, being creative, and not consumptive is something that needs to be instilled in the child.

4. Sharpening the will and ability to fight on Millennials;

The ease of obtaining information, thanks to the rapidly advancing technology, can cause children to be lazy to explore many things. Millennials parents must continue to hone the will and drive of Millennials.

Do not always tell them to get all the answers through the internet, but instead accompany them to explore the environment by doing small studies that will sharpen their thinking power.

5. Familiarise the Millennials to socialize;

When using a gadget, one's behaviour will be prone to individualistic preoccupation and less care of the environment. These behaviours might affect the ability to socialize and become a threat to the Millennial generation. Therefore, the role of parents is crucial for the child's personality.

Watching Youtube, social media, music, playing games, or something else might calm someone down, but these methods are not enough. Millennials must be wise in using the gadget. This does not mean a complete ban, but rather to limit its use to avoid being obsessed with it.

Parents can play a role in diverting the Millennial generation from boredom by doing fun activities such as gardening, making crafts, exercising, or other things that can sharpen their abilities for growth and development.

\section{CONCLUSION}

The results of the data analysis show that the condition of moral values and character of the millennial generation are in the high category, so are the social, environmental, and religious conditions. Therefore, the character building of the Millennial generation by employing a system of moral therapy based on the teachings of the Wali in the Nazam Azkiya manuscript is by first, instilling religious norms from an early age. Second, teaching the importance of courtesy. Third, instilling family values since childhood. Fourth, sharpening their will and drive. Fifth, familiarising them in socializing.

An important benefit of this therapeutic system is the development of character for the Millennial generation, mainly in instilling intelligence, virtue and moral character, beneficial to others, can use gadgets and technology appropriately, and according to their functions. Additionally, the Millennial generation should always be accompanied by religious teachings that can shape them into individuals with good disposition and morality.

\section{LIMITATION AND STUDY FORWARD}

No study covers all aspects of the research problem. Likewise, this research has also some limitations. The study is limited to the short sample size. Further research is required on larger data to increase the generalizability of its findings. Also, further research can focus on the role of culture in child character building.

\section{ACKNOWLEDGMENT}

We would like to express the appreciation to the research participants for their response and feedback throughout the data collection process. Thank you so much. Besides, there was no financial support to conduct this study.

\section{AUTHORS CONTRIBUTION}

Eka Kurnia Firmansyah wrote the research paper and design the organization of this paper; Titin Nurhayati Mamun and Ade Kosasih perform the statistical analysis, interpretations, and technical parts. Thus, all authors contributed significantly to this research. 


\section{REFERENCES}

1. Al Malibari, Z. A. (2004). Method of the heart revolution. Jakarta, Indonesia. Kalm Mulia.

2. Alam, W. Y., Marijan, K., Aminah, S., \& Putranto, T. D. (2020). Drug Eradication In Indonesian Millennials Through School Visits. Journal of Drug and Alcohol Research, 9(1), 1-6.

3. Ali, H., \& Purwandi, L. (2017). Millennial archipelago understands its character,grab the sympathy. Jakarta, Indonesia: PT Gramedia Pustaka Utama.

4. Al-khresheh, M., Khaerurrozikin, A., \& Zaid, A. (2020). The efficiency of using pictures in teaching speaking skills of non-native Arabic beginner students. Universal Journal of Educational Research, 8(3), 872-878. https://doi.org/10.13189/ujer.2020.080318

5. Balda, J. B., \& Mora, F. (2011). Adapting leadership theory and practice for the networked, millennial generation. Journal of Leadership Studies, 5(3), 13-24. https://doi.org/10.1002/jls.20229

6. Bell, T. (2005). Behaviours and attitudes of effective foreign language teachers: Results of a questionnaire study. Foreign Language Annals, 38(2), 259-270. https://doi.org/10.1111/j.1944-9720.2005.tb02490.x

7. Burstein, D. D. (2013). Fast Future: How the millennial generation is shaping our world. Beacon Press.

8. Chaudhuri, J. D. (2020). Stimulating intrinsic motivation in millennial students: A new generation, a new approach. Anatomical Sciences Education, 13(2), 250-271. https://doi.org/10.1002/ase.1884

9. Cody, F. (2020). Millennial turbulence: The networking of Tamil media politics.Television \& New Media, 21(4), 392-406. https://doi.org/10.1177/1527476419869128

10. Daradjat, Z. (1982). Religious education in mental education. Jakarta, Indonesia: BulanBintang.

11. DiLullo, C., McGee, P., \& Kriebel, R. M. (2011). Demystifying the Millennial student: A reassessment in measures of character and engagement in professional education. Anatomical Sciences Education, 4(4), 214226. https://doi.org/10.1002/ase. 240

12. Dolby, N. (2014). The future of empathy: Teaching the millennial generation. Journal of College and Character, 15(1), 39-44. https://doi.org/10.1515/jcc-2014-0006

13. Etgar, R., \& Tamir, E. (2020). Are millennial students better equipped to overcome choice bias?. International Journal of Adolescence and Youth, 25(1), 373-381. https://doi.org/10.1080/02673843.2019.1657026

14. Gani, A. (2019). Urgency Education Morals of Sufism in the Millennial Era.Journal for the Education of Gifted Young Scientists, 7(3), 499-513. https://doi.org/10.17478/jegys.603574

15. Gurman, A. S., \& Fraenkel, P. (2002). The history of couple therapy: A millennial review. Family Process, 4l(2), 199-260. https://doi.org/10.1111/j.1545-5300.2002.41204.x

16. Hidayatullah, S., Waris, A., \& Devianti, R. C.(2018). Millennial generation behaviour in using the go-food application. Journal of Management and Entrepreneurship. 6(2), 240-249. https://doi.org/10.26905/jmdk.v6i2.2560

17. Hulukati, W. W., Hulukati, W., \& Rahim, M. (2019, December). The Role of Guidance and Counseling in the Millennial Generation Character Building. In 5th International Conference on Education and Technology (ICET 2019). Atlantis Press. https://doi.org/10.2991/icet-19.2019.33

18. Kundanis, R. M. (2003). Children, teens, families, and mass media: The millennial generation. Routledge. https://doi.org/10.4324/9781410607805

19. Malo, M. (1985). Social research methodology. Jakarta, Indonesia: Komunika.

20. Petersen, M. (2020). Stewarding Privilege: Transitioning to Millennial Leadership in Christian Family Foundations.

21. Pirie, M., \& Worcester, R. M. (1998). The millennial generation. London: Adam Smith Institute.

22. Rebollo, H. P. M. (2018). A structural model of millennial tourist behaviour towards tourism in Davao Region. Journal of Advances in Humanities and Social Sciences, 4(1), 26-36. https://doi.org/10.20474/jahss-4.1.3

23. Ronda, L., Valor, C., \& Abril, C. (2020). How small traditional businesses can become attractive employers: A

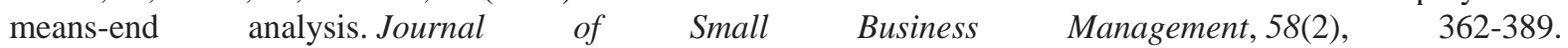
https://doi.org/10.1080/00472778.2019.1659682

24. Sandfort, M. H., \& Haworth, J. G. (2002). Whassup? A glimpse into the attitudes and beliefs of the millennial generation. Journal of College and Character, 3(3). https://doi.org/10.2202/1940-1639.1314

25. Shams, D. (2016). The use of stories in promoting morality among junior high school students. Journal of Advances in Humanities and Social Sciences, 2(3), 168-181. https://doi.org/10.20474/jahss-2.3.5

26. Sugiyono. (2010). Educational research methods. Bandung, Indonesia: Alfabeta.

27. Sumartono. (1998). The effect of shampoo advertising on television against adolescent consumer attitudes and behaviours. Bandung, Indonesia: PPS-Unpad.

28. Teng, F., Quoquab, F., Hussin, N., \& Mohammad, J. (2016). Re-defining sustainable development values and its facets based on developing country perspective. Journal of Advances in Humanities and Social Sciences, l(2), 1-13. https://doi.org/10.20474/jahss2.1.1

29. Wahana, H. D. (2015). The effect of millennial generation cultural values and school culture on individual resilience studies in High School 39, Cijantung, Jakarta.National Defence Journal. 21(1),14-22. https://doi.org/10.22146/jkn.6890 
Humanities \& Social Sciences Reviews

elSSN: 2395-6518, Vol 8, No 3, 2020, pp 972-989

https://doi.org/10.18510/hssr.2020.83101

30. Wibowo, F. C., Nurhaji, S., Setiawan, A., Sugiyarto, W. A., Noor, M., Faizin, D. R. D., ... \& Coştu, B. (2018). The Influences Virtual Physics Laboratory (VPL) For Assessment the Millennial Character Education through System Recording Students Character (SRSC). Journal of Education and Learning (EduLearn), 12(4), 709-716. https://doi.org/10.11591/edulearn.v12i4.9923 